\title{
The Effects of Corporate Ownership Structure and Board Size on Earnings Management: Evidence from Turkey
}

\author{
Mehmet Aygun ${ }^{1}$, Suleyman $\mathrm{Ic}^{2} \&$ Mustafa Sayim ${ }^{3}$ \\ ${ }^{1}$ Faculty of Economics and Administrative Sciences, Yüzüncü Yil University, Van, Turkey \\ ${ }^{2}$ Faculty of Economics and Administrative Science, Ondokuz Mayis University, Samsun, Turkey \\ ${ }^{3}$ Alliant School of Management, Alliant International University, San Diego, CA, USA \\ Correspondence: Mustafa Sayim, Alliant School of Management, Alliant International University, San Diego, \\ CA, USA. E-mail: msayim2@alliant.edu
}

Received: September 2, 2014

Accepted: October 8, $2014 \quad$ Online Published: November 22, 2014

doi:10.5539/ijbm.v9n12p123

URL: http://dx.doi.org/10.5539/ijbm.v9n12p123

\begin{abstract}
This study investigates the impact of corporate ownership structure and board size on earnings management for a sample of Turkish firms registered on the Istanbul Stock Exchange (ISE) for the period of 2009 to 2012. The corporate ownership structure is measured with two variables: managerial ownership and institutional ownership. The board size can be defined as the number of members in the board. This study also uses three controlled variables: return on assets, size of the firm and financial leverage. The adjusted Jones Model (Dechow, Sloan and Sweeney, 1995) and the multivariate regression technique are utilized to examine the effect of corporate ownership structure and board size on earnings management. The results consistent with the previous studies show that the institutional ownership and the board size have a negative significant effect on the earnings management while the effect of the managerial ownership on the earnings management has positively statistically significant. The findings also reveal that the return on assets has a positively statistically significant effect on earnings management. However, the impact of the financial leverage on earnings management is negatively statistically significant.
\end{abstract}

Keywords: earnings management, ownership structure, discretionary accruals

\section{Introduction}

Accounting earnings is commonly used and most accepted method to measure a firm's financial performance. However, the disclosed financial statements can be utilized by firms as the Generally Accepted Accounting principles (GAAP) allow as an alternate accounting method. Earnings management can be considered as legal if a firm adjusts the disclosed earnings in guidelines with GAAP for instance changing the approaches for current assets such as inventory valuation and depreciation. On the other hand, earnings management turns into fraudulent activities when it does not comply with the GAAP standards such as accelerating revenue recognition and deferring expenses recognition (Yang, Chun \& Ramadili, 2009). Therefore, earnings management might be the way to manipulate a firm's disclosed financial statements both to misinform stockholders and to affect contractual benefit that is based on accounting earnings (Healy \& Wahlen, 1999). Schipper (1989) also defines earnings management is one of the deliberate interventions in financial reporting process to achieve personal objectives rather than to maximize the shareholder values. This may result in the falsification of financial statement by managers, using accounting techniques and predicts to reach some objectives that create a conflict with the shareholders' value maximization approach.

In the last two decades due to large corporate scandals and failures in the US earnings management has been drawn attention by the scholars, the regulators and the practitioners and has been comprehensively studied in the finance literature. Some of the notable papers in which the impact theoretical foundation of the board size and ownership structure on earnings management have been developed are Dechow, Sloan and Sweeney (1996); Eisenberg, Sundgren and Wells (1998); Jensen (1993); Healy and Wahlen (1999); Jones (1991); Shaikh, Iqbal and Shah (2012); and Teoh, Welch and Wong (1998).

Earlier studies have mostly focused on both the factors limiting earnings management and incentives of earnings management. A partial list of these studies include Guidry, Leone and Rock (1999); Healy (1985); and 
Holthausen, Larcker and Sloan (1995). However, some studies reveal that some corporate governance factors have an effect on the earnings management; for instance, Dechow et al. $(1995,1996)$ suggest that large block-stockholders have ability to improve accuracy of financial statements of a firm by oversighting its earnings of management activities. Warfield, Wild and Wild (1995) discuss that managers who own a large percentage of stocks of a firm are less likely to be motivated to altering disclosed financial statements. In addition, institutional investors have more capability to detect earnings management than individual investors because of ability to access relevant information in timely manner (Balsam, Bartov \& Marquardt (2002). Therefore finance literature reveal that a firm's ownership structure is considered one of the important factors limiting earnings management.

Thus, the results of earnings management methods cannot be generalized for each country. Each country must be studied independently to determine the impact, relevance and applicability of the models. Therefore, this study examines the effect of board size and corporate ownership structure on earnings management for a sample of Turkish firms registered on the Istanbul Stock Exchange (ISE) for the period of 2009 to 2012. The findings show that the institutional ownership and the board size have a negative significant effect on the earnings management while the effect of the managerial ownership on the earnings management has positively statistically significant. The results also reveal that the return on assets has a positively statistically significant effect on earnings management. However, the effect of the financial leverage on earnings management is negatively statistically significant.

Based on our best knowledge, this paper is to be the first to examine the impact of board size and ownership structure on earnings management in Turkey. The results of this paper can provide helpful information to investors in evaluating the ownership structure effect on earnings management. The findings can also help policymakers to design policies that reduce uncertainty in disclosing of a firm's financial and economic performance.

The rest of the study is organized as follows. Section 2 examines literature review, Section 3 presents the model and methodology, Section 4 discusses data, Section 5 evaluates the findings and finally, Section 6 concludes the study.

\section{Literature Review}

\subsection{Earnings Management and Ownership Structure}

In corporation management and ownership are separated. This creates conflict called agency problem (Jensen \& Meckling, 1976). According to this theory sometimes managers do not want to act in behalf of shareholders to maximize their values. Therefore, it becomes essential to monitor decisions of managers to make sure shareholders' values are increased and disclosed financial statements are accurate and transparent. The properly well-established corporate control structures are tended to decrease earnings management manipulation (Alves, 2011; Bushman \& Smith, 2003; Chen, Jean \& Haitao, 2012; Dechow et al., 1996). Following Alves (2011) to research the ownership structure impact on earnings management, this paper uses two types of ownership structures: managerial ownership and institutional ownership.

\subsubsection{Earnings Management and Managerial Ownership}

According to the agency hypothesis (Jensen \& Meckling, 1976), separation of management and ownership in a corporation lead to agency problems that reduce the firm's value due to agency conflicts. It also suggests if managers do not have a high level of shares in the firm, they may not act most likely in behalf of shareholders. A higher level of managerial ownership is considered as one of the important incentives to motivate managers (Warfield et al., 1995). As a result, employee stock ownership or option can reduce the conflict between managers and stockholders with the interest alignment hypothesis which is developed by La Porta, Lopez-de-Silanes, \& Shleifer (1999) and Claessens, Djankov \& Lang (2000). It can be expected when managerial ownership increases, the incentives to altering earnings will reduce. On the other hand, the entrenchment hypothesis by Stulz (1988) suggests that managers own a large level of ownership may manipulate earnings management to maximize their own personal objectives (Cheng \&Warfield, 2005; Healy, 1985; Holthousen et al., 1995). Previous studies reveal the findings consistent with two hypotheses.

Warfield et al. (1995) examines the managerial ownership effect on earnings management. The findings suggest that the relation between those two variables is a statistically significantly negative. Another study conducted by Gabrielsen Jeffrey and Thomas (2002) also reveal that the ownership structure found in different countries, including Denmark, deviates from the US ownership configuration and the findings indicate that managerial ownership effect on earnings management is a negatively statistically significant.

Yeo, Tan, Hoand Chen (2002) in contrast to prior studies find out that a non-linear relation exists between 
earnings management and managerial ownership in Singapore. Sanchez-Ballesta and Garcia-Meca (2007) by using panel data approach to investigate the relationship among ownership structure, discretionary accruals and the informativeness of earnings for Spanish non-financial firms for the period 1999-2002 also suggest the relationship is a non-linear between insider ownership and discretionary accruals and between insider ownership and earnings explanatory power for returns. Teshima and Shuto (2008) investigate the managerial ownership and opportunistic managerial behavior effects related to earnings management on Japanese firms. The result documents that as managerial ownership rises, earnings management reduces not only large levels of managerial ownership but also low levels of managerial ownership. The study conducted by Yang, Lai and Tan (2008) on the firms quoted on the Taiwanese Stock Market for the period 1997-2004 suggest that the relation between earnings management and managerial ownership is a positively statistically significant. On the other hand, Gulzar and Wang (2011) find the relation between earnings management and managerial ownership is a negatively statistically significant on Chinese firms.

As can be seen from earlier studies the impacts of managerial ownership on earnings management reveal the mixed results. Therefore, Hypothesis 1 is non-directional as follows:

Hypothesis 1: The relation between earnings management and managerial ownership is statistically significant.

\subsubsection{Earnings Management and Institutional Ownership}

Previous studies suggest that a high level of institutional ownership can play a crucial role on corporate governance mechanism (Alves, 2011). The efficient monitoring hypothesis suggests that institutional investors can have abilities and resources to monitor managers effectively in comparison to individual investors. This would lower the capability of managers to manage the firm's accounting earnings (Chung, Firth and Kim 2002; Koh, 2003). Therefore, there is an inverse relation between earnings management and institutional ownership. However, earlier studies on the institutional ownership effects on earnings management reveal the mixed results.

Koh (2003) investigates the relation between firms' aggressive earnings management strategies and institutional ownership in Australia. The relation between firms' income increasing discretionary accruals and institutional ownership is expected to vary as the proportion of institutional ownership structure changes. Koh (2003) suggest that there is a positive relation existing at the lower institutional ownership. This may suggest that institutional investors provide incentives for managers to manage earnings. On the other hand, there is a negative relation found at the higher proportion of institutional ownership indicating institutional investors' monitoring is one of the factors limiting managerial accruals discretion.

Al-Fayoumi, Abuzayed and Alexander (2010) examine the institutional investors effects on discretionary accruals in the Nigerian manufacturing firms registered on the Nigerian Stock Exchange for the period of 2008 to 2010. The empirical results reveal that institutional investors' effect is a statistically positively significant on earnings management in the Nigerian manufacturing companies.

Another study conducted by Senteza and Gill (2005) suggests that a high percentage of institutional investor's ownership in firms that manages earnings upwards and a low proportion of ownership in companies that manipulate earnings before end-of-year reporting in the US. Cheng and Reitenga (2009) find the similar findings. They predict that ACTB (Active institutional block holders) will want to utilize their controlling ability only when EP (Earning Pressure) is strong. Al-Abbas (2009) also documents that there is a statistically significantly relation exist between earnings management and institutional ownership on the companies listed in Saudi Arabian Stock Market.

The study conducted by Jouber and Fakhfakh (2012) shows that some of the strong earnings factors are CEO stock ownership, independent monitoring and institutional investor's property in both the French and Canadian structures. On the other hand, Yang et al. (2009) examine the external directors and institutional shareholders roles in limiting the earnings management activities on Malaysian companies. The finding shows that the relation between earnings management and institutional ownership is statistically insignificant.

Emamgholipour, Bagheri, Mansourinia and Arabi (2013) examine the relationship between earnings management and institutional investors on registered firms on the Tehran Stock Exchange by examining a sample of 700 companies for the period 2006 to 2010. The findings show that a positive and significant relationship between earnings management and institutional investors. This suggests that increasing the ownership levels of institutional shareholders increases the possibility earnings management.

Iqbal and Strong (2010) examine the board structure, ownership structure, adviser structure, and capital structure effects on discretionary short-term accruals. The empirical findings show that companies with higher debt to equity ratios, with lower proportions of non-executive directors, or with no high level of block owners, are more 
likely to use discretionary short-term accruals to alter earnings.

As can be seen from earlier studies the institutional ownership effects on earnings management reveal the mixed results. Therefore, Hypothesis 2 is non-directional as follows:

Hypothesis 2: The relation between earnings management and institutional ownership is statistically significant.

\subsubsection{Earnings Management and Board Size}

Board can be viewed as one of the important internal monitoring mechanisms that may have an effect on a company's earnings management. Gonzalez and Garcia-Meca (2014) study the relation between earnings management measured by discretionary accrual and the internal mechanisms of corporate governance. By using an example of registered Latin American non-financial firms for the period of 2006 to 2009, they document the external directors role is limited in the Latin American frameworks. In addition, if boards meet more often they take a very active roleto monitor insiders' conducts. This may result in reducing the manipulative activities. They find a non-linear relation between discretionary accruals and insider ownership. This may indicate when the percentage of ownership of main shareholders is moderate ownership structure may be a manipulative activity.

Loderer and Peyer (2002)investigate the board overlap among companies registered in Switzerland. They document that there is an inverse relationship between board size and firm value, possibly due to the agency problem. Jensen (1993) has questioned the performance of large boards because of those problems of poor communication and decision-making overwhelming the effectiveness of board. Yermack (1996) discusses a proposal reducing the number of corporate boards of directors. He finds evidence that there is an inverse relation between firm value and board size.

Vafeas (2000) investigates if the informativeness of earnings, proxied by the earnings and returns relationship, changes with the proportion of external directors being a part of board. A small board size might be an effective technique in attaining higher quality controlling. Ching, Firth and Rui (2006), Dechow et al. (1996), Gonzalez and Garcia-Meca (2014), Rahman and Ali (2006), and Santiago \&Brown (2009) suggest that the association between the earnings management and board size is positively statistically significant. On the other hand, Abed, Al-Attar and Suwaidan (2012); Ghosh, Marraand Doocheol (2010), Davidson, Goodwin and Kent (2005), Peasnell, Pope and Young (2005), and Xie, Davidson and DaDalt (2003) there is a negatively statistically significant relationship between the earnings management and the board size. Therefore, earlier studies reveal the mixed results on the board size effect on the earnings management. Hypothesis 3 is non-directional as follows:

\section{Hypothesis 3: The relation between earnings management and board size is statistically significant.}

\section{Research Methodology and Model}

This study examines the corporate ownership structure and board size effects on earnings management for an example of Turkish companies registered on the Istanbul Stock Exchange (ISE) for the period of 2009 to 2012. The number of firms from varies industries included in this study is 230. The financial companies such as banks, insurance companies are excluded from the research because of their different capital structure (Klein, 2002).

The data on the earnings management, corporate ownership structure, board size, firm size and financial leverage are obtained from the Public Disclosure Platform (PDP) database.

\subsection{Research Variables}

\subsubsection{Dependent Variables}

This study uses earnings management as a dependent variable. This study employs a discretionary accruals (DACC) approach for measuring earnings that is similar to the methodologies used by Alves, 2011; Teoh et al., 1998; Xie et al., 2003; Gonzalez et al., 2013. Dechow et al. (1995) suggested that the Modified Jones Model (1991) is one of the most commonly used and accepted approach for estimating discretionary accruals. Therefore, the following the models presented by Jones (1991) and Dechow et al. (1995), DACC is measured as follows:

$$
D A C C_{i t}=T A C C_{i t} / A_{i t-1}-\left[\hat{\alpha}_{t}\left(1 / A_{i t-1}\right)\right]+\hat{\alpha}_{1 i}\left[\left(\Delta R E V_{i t}-\Delta R E C_{i t}\right) / A_{i t-1}\right]+\hat{\alpha}_{2 i}\left[P P E_{i t} / A_{i t-1}\right]
$$

Where DACC $\mathrm{it}_{\mathrm{it}}$ is the discretionary accruals for firm $i$ in year $t, \mathrm{TACC}_{\mathrm{it}}($ Note 1$)$ is the total accruals for firm $i$ in year $t, \Delta \mathrm{REV}_{i t}$ is the change in operating revenues for firm $i$ in year $t, \Delta \mathrm{REC}_{i t}$ is the receivables for firm $i$ in year $t, \mathrm{PPE}_{i t}$ is the gross property, plant and equipment for firm $i$ in year $t$ and $\mathrm{A}_{i t-1}$ is the lagged total asset for firm $i$.

\subsubsection{Independent Variables}

As pointed out previously, the following the study of Alves (2011) to examine if a firm's ownership structure has 
an effect on the earnings management, this study uses three independent variables: managerial ownership, institutional ownership and board size. The following the methodology of Alves (2011), the managerial ownership is calculated as the proportion of the firm's shares owned by the mangers; the institutional ownership is measured as the proportion of the firm's shares held by the institutional investors. The board size is the number of members in the board.

\subsubsection{Control Variables}

Some factors other than firm ownership structure may also have an impact on earnings management. Therefore, this study employees three control variables: return on asset, financial leverage and firm size. The return on asset is the net income divided by total assets.

Existing literature suggested that there is a negative relationship between earnings management and firm size (Klein, 2002; Xie et al., 2003; Rahman \& Ali, 2006). This indicates that smaller firms are subject to less monitoring from owner so that managers can engage more in earnings management activities. Therefore, this study defines the firm size as the natural logarithm of the firm's total assets (Abed et al., 2011).

Earlier studies documented that managers with high debt ratios have strong incentives to utilize income increasing accruals to lower the contractual debt obligations (Ali, Salleh \& Hassan, 2008; Jiang, Lee \& Anandarajan, 2008). In addition, there is an inverse relationship between financial leverage and earnings management (Ching, Firth \& Rui, 2002; Park \& Shin, 2004; Yang, Lai \& Tan, 2008). Therefore, the financial leverage of a firm is the total debt to total assets.

\subsection{Research Model}

The study the following Alves (2011) evaluates the relationship between earnings management and owner structure by assessing the following OLS regression equations:

MODEL 1:

$$
D_{A C C_{i t}}=\beta_{o}+\beta_{1}\left(\text { Managerial }_{i t}\right)+\beta_{2}\left(\text { ROA }_{i t}\right)+\beta_{3}\left(\text { Leverage }_{i t}\right)+\beta_{4}\left(\text { Size }_{i t}\right)+\varepsilon_{i t}
$$

MODEL 2:

$$
D A C C_{i t}=\beta_{o}+\beta_{1}\left(\text { Institutional }_{i t}\right)+\beta_{2}\left(\text { ROA }_{i t}\right)+\beta_{3}\left(\text { Leverage }_{i t}\right)+\beta_{4}\left(\text { Size }_{i t}\right)+\varepsilon_{i t}
$$

MODEL 3:

$$
D_{A C C_{i t}}=\beta_{o}+\beta_{1}\left(\text { Board }_{i t}\right)+\beta_{2}\left(\text { ROA }_{i t}\right)+\beta_{3}\left(\text { Leverage }_{i t}\right)+\beta_{4}\left(\text { Size }_{i t}\right)+\varepsilon_{i t}
$$

MODEL 4:

$$
D A C C_{i t}=\beta_{o}+\beta_{1}\left(\text { Managerial }_{i t}\right)+\beta_{2}\left(\text { Institutional }_{i}\right)+\beta_{3}\left(\text { Board }_{i t}\right)+\beta_{4}\left(\text { ROA }_{i t}\right)+\beta_{5}\left(\text { Leverage }_{i t}\right)+\beta_{6}\left(\text { Size }_{i t}\right)+\varepsilon_{i t}
$$

where DACC ${ }_{i t}$ is the discretionary accruals for firm $i$ in year $t$ by using the modified Jones model; Managerial ${ }_{i t}$ is the proportion of the firm's shares owned by the mangers; Institutional ${ }_{i t}$ is the institutional ownership is measured as the proportion of the firm's shares held by the institutional investors; Board ${ }_{i t}$ is the board size is the number of members in the board; $R O A_{i t}$ is the net income to total asset; Leverage $_{i t}$ is the total debt to total assets; Size $_{i t}$ is the natural logarithm of the firm's total assets; $\beta_{o}$ is the constant; $\beta_{1}$ to $\beta_{6}$ are the coefficients to be estimated; and $\varepsilon_{i t}$ is the residual term of firm $i$ for year $t$.

Table 1 is the summary statistics of the variables in this study. The mean of DACC is -0.0077 with the minimum of -0.7300 and the maximum of 0.9700 . This may suggest Turkish companies are managing their earnings downwardly. The means of institutional ownership and managerial ownership are 0.576 and 0.5178 respectively, suggesting that more than $50 \%$ of stocks held by the institutional owners in Turkey. The size of directors in the board is 7 as an average. The means of ROA and leverage of the firms are $3.15 \%$ and $44.89 \%$ respectively during the sample period. 
Table 1. Descriptive statistics of variables number of observations: 890; period 2009-2012

\begin{tabular}{lllll}
\hline & Mean & Minimum & Maximum & Std. Dev. \\
\hline DACC & -0.0077 & -0.7300 & 0.9700 & 0.1353 \\
Managerial & 0.0576 & 0.0000 & 0.8000 & 0.1661 \\
Institutional & 0.5178 & 0.0000 & 0.9900 & 0.3099 \\
Board & 7.0225 & 3.0000 & 14.0000 & 2.0575 \\
ROA & 0.0315 & -0.3700 & 0.8400 & 0.1002 \\
Leverage & 0.4489 & 0.0100 & 0.9100 & 0.2326 \\
Size & 8.0442 & 5.7100 & 10.2700 & 0.8327 \\
\hline
\end{tabular}

Note. DACC is the earning management, Managerial is the proportion of the firm's shares owned by the mangers; Institutional is the institutional ownership is measured as the proportion of the firm's shares held by the institutional investors; Board is the board size is the number of members in the board; ROA it is the net income to total asset; Leverage is the total debt to total assets; Size it is the natural logarithm of the firm's total assets.

Table 2 shows the cross-correlations among the variables. The correlations among the variables appear to be low less than 0.9 thresholds, indicating the variables do not have multi collinearity problems (Tabachnick \& Fidell, 2001).

Table 2. Cross-Correlations of variables

\begin{tabular}{|c|c|c|c|c|c|c|c|}
\hline & DACC & Managerial & Institutional & Board & ROA & Leverage & Size \\
\hline DACC & 1.000 & & & & & & \\
\hline Managerial & $0.083^{*}$ & 1.000 & & & & & \\
\hline Institutional & $-0.144 * *$ & $-0.573 * *$ & 1.000 & & & & \\
\hline Board & -0.034 & $-0.186^{* *}$ & $0.311^{* *}$ & 1.000 & & & \\
\hline ROA & $0.334 * *$ & -0.071 & $0.174 * *$ & $0.213^{* *}$ & 1.000 & & \\
\hline Leverage & $-0.154 * *$ & 0.042 & -0.049 & -0.006 & $-0.263 * *$ & 1.000 & \\
\hline Size & 0.003 & $-0.101 * *$ & $0.172 * *$ & $0.214 * *$ & $0.097 * *$ & 0.050 & 1.000 \\
\hline
\end{tabular}

Note. DACC is the earning management, Managerial is the proportion of the firm's shares owned by the mangers; Institutional is the institutional ownership is measured as the proportion of the firm's shares held by the institutional investors; Board is the board size is the number of members in the board; ROA it is the net income to total asset; Leverage is the total debt to total assets; Size it is the natural logarithm of the firm's total assets. *, **, and *** denote significance level at the $10 \%, 5 \%$, and $1 \%$.

\section{Empirical Results}

Table 3 shows the results of regression equations of 1, 2, 3 and 4 in the research model.

Model 1: $D A C C_{i t}=\beta_{o}+\beta_{1}\left(\right.$ Managerial $\left._{i t}\right)+\beta_{2}\left(\right.$ ROA $\left._{i t}\right)+\beta_{3}\left(\right.$ Leverage $\left._{i t}\right)+\beta_{4}\left(\right.$ Size $\left._{i t}\right)+\varepsilon_{i t}$

Model 2: $D A C C_{i t}=\beta_{o}+\beta_{I}\left(\right.$ Institutional $\left._{i t}\right)+\beta_{2}\left(\right.$ ROA $\left._{i t}\right)+\beta_{3}\left(\right.$ Leverage $\left._{i t}\right)+\beta_{4}\left(\right.$ Size $\left._{i t}\right)+\varepsilon_{i t}$

Model 3: $D A C C_{i t}=\beta_{o}+\beta_{I}\left(\right.$ Board $\left._{i t}\right)+\beta_{2}\left(\right.$ ROA $\left._{i t}\right)+\beta_{3}\left(\right.$ Leverage $\left._{i t}\right)+\beta_{4}\left(\right.$ Size $\left._{i t}\right)+\varepsilon_{i t}$

Model 4: $D_{A C C_{i t}=} \beta_{o}+\beta_{1}\left(\right.$ Managerial $\left._{i t}\right)+\beta_{2}\left(\right.$ Institutional $\left._{i t}\right)+\beta_{3}\left(\right.$ Board $\left._{i t}\right)+\beta_{4}\left(\right.$ ROA $\left._{i t}\right)+\beta_{5}\left(\right.$ Leverage $\left._{i t}\right)+\beta_{6}($ Size $\left.{ }_{i t}\right)+\varepsilon_{i t}$ 
Table 3. Results of regression equations

Dependent Variable: DACC

Model 1Model 2Model 3Model 4

\begin{tabular}{|c|c|c|c|c|c|c|c|c|}
\hline Variable & Coeffi. & $t$-Statistic & Coeffi. & $t$-Statistic & Coeffi. & $t$-Statistic & Coeffi. & $t$-Statistic \\
\hline Constant & 0.018 & 0.429 & 0.040 & 0.966 & 0.056 & 1.328 & 0.052 & 1.240 \\
\hline Managerial & 0.107 & $3.368 * * *$ & & & & 1.323 & 0.084 & $2.546^{* * *}$ \\
\hline Institutional & & & -0.209 & $-6.602 * * *$ & & & -0.204 & $-5.200 * * *$ \\
\hline Board & & & & & -0.104 & $-3.184 * * *$ & -0.060 & $-2.474 * * *$ \\
\hline ROA & 0.324 & $9.889 * * *$ & 0.351 & $10.786 * * *$ & 0.340 & $10.164 * * *$ & 0.360 & $10.907 * * *$ \\
\hline Leverage & -0.072 & $2.212 * * *$ & -0.072 & $-2.247 * * *$ & -0.065 & $-1.982 * *$ & -0.069 & -2.165 \\
\hline Size & -0.020 & -0.617 & 0.003 & 0.0906 & -0.010 & -0.308 & 0.011 & 0.341 \\
\hline Adjusted $\mathrm{R}^{2}$ & 0.124 & & 0.155 & & 0.123 & & 0.155 & \\
\hline F-Statistic & $32.521 * * *$ & & $41.651 * * *$ & & $32.179 * * *$ & & $28.221 * * *$ & \\
\hline
\end{tabular}

Note. DACC is the earning management, Managerial is the proportion of the firm's shares owned by the mangers; Institutional is the institutional ownership is measured as the proportion of the firm's shares held by the institutional investors; Board is the board size is the number of members in the board; ROA it is the net income to total asset; Leverage is the total debt to total assets; Size it is the natural logarithm of the firm's total assets. ${ }^{*}, *$, and $* * *$ denote significance level at the $10 \%, 5 \%$, and $1 \%$.

Model 1 examines the relationship between earnings management and managerial ownership. Consistent with the alignment of interest hypothesis the result shows that there is a statistically positively significant relationship between the earnings management and the managerial ownership (Stulz, 1988; Gabrielsen et. al., 2002, Alves, 2011). This suggests that the high level of managerial ownership means the higher magnitude of discretionary accounting accruals. Therefore, Hypothesis 1, the relationship between earnings management and managerial ownership is statistically positively significant, was supported.

In model 2, the relationship between earnings management and institutional ownership is investigated. The findings suggest that the intuitional there is a statistically negatively significant inverse relationship between earnings management and institutional ownership. This negative relationship is consistent with the previous studies (Ali, Salleh \& Hassan, 2008; Iturriaga \& Hoffman, 2005) reveals that earnings management may be significantly decreased by the firms with higher percentage of intuitional ownership. In other words, an increase in institutional ownership would reduce the discretionary accounting accrual activities. Therefore, Hypothesis 2 , the relationship between earnings management and institutional ownership is statistically negatively significant, was supported.

Model 3 examines the relationship between earnings management and board size. As it can be from Table 3, the relationship is statically negatively significant. This negative relationship suggests that the less number of directors on the board would most likely to eliminate uses of accruals to manipulate earnings (Alves, 2011). As a result, Hypothesis 3, the relationship between earnings management and board size is statistically negatively significant, was also supported.

Model 4 in Table 3 presents the results of multivariate regression equations. The findings reveal that the impact of institutional ownership, board and leverage on earnings management is statistically negatively significant. On the other hand, the impact of managerial ownership on earnings management is statistically positively significant in all models. Although there is a positive relationship between earnings management and board size, it is not significant statistically.

\section{Conclusion}

Previous studies in the literature suggested that ownership structure is one of the important factors having an impact on corporate earnings management (Chung at al, 2002; Dechow et al, 1996; Eisenberg et al, 1998). Therefore, the purpose of this study is to examine the corporate ownership structure and board size effects on earnings management for a sample of Turkish firms quoted on the Istanbul Stock Exchange (ISE) for the period of 2009 to 2012. The findings revealed that the Turkish firms' ownership structure also affect earnings management. The adjusted Jones Model (Dechow et al., 1995) and the multivariate regression model were utilized to examine the effect of board size and corporate ownership structure on earnings management. The results consistent with the earlier researches such as Al-Fayoumi et al. (2010); Koh, (2003); Teshima \& Shuto, (2008); and Yang et al., (2008) showed that the institutional ownership and the board size have a negative significant effect on the earnings management while the effect of the managerial ownership on the earnings 
management has positively statistically significant. The findings also reveal that the return on assets has a positively statistically significant effect on earnings management. However, the impact of the financial leverage on earnings management is negatively statistically significant.

The results of this paper can provide helpful information to investors in evaluating the board size and ownership structure effects on earnings management in Turkey. The findings can also help policymakers to design policies that reduce uncertainty in disclosing the results of a firm's financial and economic performance.

\section{References}

Abed, S., Al-Attar, A., \& Suwaidan, M. (2012). Corporate Governance and Earnings Management: Jordanian Evidence. International Business Research, 5(1), 216-225.

Al-Abbas, M. (2009). Corporate Governance and Earnings Management: An Empirical Study of the Saudi Market. The Journal of American Academy of Business, 15(1), 301-310.

Ali, S. M., Salleh, N. M., \& Hassan, M. S. (2008). Ownership structure and earnings management in Malaysian listed companies: the size effect. Asian Journal of Business and Accenting, 1(2), 89-116.

Al-Fayoumi, N., Abuzayed, B., \& Alexander, D. (2010). Ownership structure and earnings management in emerging markets: The case of Jordan. International Research Journal of Finance and Economics, 38, $28-47$.

Alves, S. M. G. (2011). The effect of the board structure on earnings management: evidence from Portuga. Journal of Financial Reporting and Accounting, 9(2), 141-160. http://dx.doi.org/10.1108/19852511111173103

Balsam, S., Bartov, E., \& Marquardt, C. (2002). Accruals management, investor sophistication, and equity valuation: Evidence from 10-Q filings. Journal of Accounting Research, 40(4), 987-1012. http://dx.doi.org/10.1111/1475-679X.00079

Bushman, R. M., \& Smith, A. J. (2003). Transparency, financial accounting information, and corporate governance. Economic Policy Review, 9(1), 65-87.

Chen, J. J., \& Haitao, Z. (2014). The impact of the corporate governance code on earning-management -Evidence from Chinese listed Companies. European Financial Management, 20(3), 596-632. http://dx.doi.org/10.1111/j.1468-036X.2012.00648.x

Cheng, C. S. A., \& Reitenga, A. (2009). Characteristics of institutional investors and discretionary accruals. International Journal of Accounting and Information Management, 17(1), 5-26. http://dx.doi.org/10.1108/18347640910967717

Cheng, Q., \& Warfield, T. D. (2005). Equity incentives and earnings management. The Accounting Review, 80(2), 441-476. http://dx.doi.org/10.2308/accr.2005.80.2.441

Ching, K. M. L., Firth, M., \& Rui, O. M. (2006). Earnings management, corporate governance and the market performance of seasoned equity offerings. Journal of Contemporary Accounting and Economics, 2(1), 73-98. http://dx.doi.org/10.1016/S1815-5669(10)70017-5

Chung, R, Firth, M., \& Kim, J. B. (2002). Institutional monitoring and opportunistic earnings management. Journal of Corporate Finance, 8, 29-48. http://dx.doi.org/10.1016/S0929-1199(01)00039-6

Claessens, S., Djankov, S., \& Lang, L. H. P. (2000). The Separation of Ownership and Control in East Asian $\begin{array}{lllll}\text { Corporation. Journal of Financial } & \text { Economics, }\end{array}$ http://dx.doi.org/10.1016/S0304-405X(00)00067-2

Davidson, R., Goodwin, J., \& Kent, P. (2005). Internal governance structures and earnings management. Accounting and Finance, 45, 241-267. http://dx.doi.org/10.1111/j.1467-629x.2004.00132.x

Dechow, P. M., Sloan, R. G., \& Sweeney, A. P. (1996). Causes and consequences of earnings manipulations: An analysis of firms subject to enforcement actions by the SEC. Contemporary Accounting Research, 13(1), 1-36. http://dx.doi.org/10.1111/j.1911-3846.1996.tb00489.x

Dechow, P. M., Sloan, R. G., \& Sweeney, A. P. (1995). Detecting earnings management. The Accounting Review, $70(2), 193-225$.

Eisenberg, T., Sundgren, S., \& Wells, M. T. (1998). Larger Board Size and Decreasing Firm Value in Small Firms. Journal of Financial Economics, 48(1), 35-54. http://dx.doi.org/10.1016/S0304-405X(98)00003-8

Emamgholipour, M., Bagheri, S., Mansourinia, E., \& Arabi, A. (2013). A study on relationship between 
institutional investors and earnings management: Evidence from the Tehran Stock Exchange. Management Science Letters, 3(4), 1105-1112. http://dx.doi.org/10.5267/j.msl.2013.03.017

Gabrielsen, G., Jeffrey, D., \& Thomas, P. (2002). Managerial ownership, information content of earnings, and discretionary accruals in a non-US setting. Journal of Business Finance \& Accounting, 29, 967-988. http://dx.doi.org/10.1111/1468-5957.00457

Ghosh, A., Marra, A., \& Doocheol, M. (2010). Corporate Boards, audit committees, and earnings management: Pre-and Post-SOX evidence. Journal of Business Finance \& Accounting, 37, 1145-1176. http://dx.doi.org/10.1111/j.1468-5957.2010.02218.x

Gonzalez, J. A. S., \& Garcia-Meca, E. (2014). Does Corporate Governance Influence Earnings Management in Latin American Markets? Journal of Business Ethic, 121(3), 419-440. http://dx.doi.org/10.1007/s10551-013-1700-8

Guidry, L. F., Leone, A. J., \& Rock, S. (1999). Earnings-based bonus plans and earnings management by business-unit managers. Journal of Accounting and Economics, 26, 113-142. http://dx.doi.org/10.1016/S0165-4101(98)00037-8

Gulzar, M. A., \& Wang, Z. (2011). Corporate Governance Characteristics and Earnings Management; Empirical Evidence from Chinese Listed Firms. International Journal of Accounting and Financial Reporting, 1(1), 133-151. http://dx.doi.org/10.5296/ijafr.v1i1.854

Healy, P. (1985). The effect of bonus schemes on accounting decision. Journal of Accounting and Economics, 7 , 85-107. http://dx.doi.org/10.1016/0165-4101(85)90029-1

Healy, P., \& Wahlen, J. (1999). A review of the earnings management literature and its implications for Standard setting. Accounting Horizons, 13(4), 365-383. http://dx.doi.org/10.2308/acch.1999.13.4.365

Holthousen, R. W., Larcker, D. F., \& Sloan, G. R. (1995). Annual bonus schemes and the manipulation of $\begin{array}{llll}\text { earnings. Journal of Accounting and Economics, } & \text { 19, }\end{array}$ http://dx.doi.org/10.1016/0165-4101(94)00376-G

Iqbal, A., \& Strong, N. (2010). The effect of corporate governance on earnings management around UK right issues. International Journal of Managerial Finance, 6(3), 168-189. http://dx.doi.org/10.1108/17439131011056215

Jensen, M. C. (1993). The Modern Industrial Revolution, Exit, and the Failure of Internal Control Systems. Journal of Finance, 3(48), 831-880. http://dx.doi.org/10.1111/j.1540-6261.1993.tb04022.x

Jensen, M. C., \& Meckling, W. H. (1976). Theory of the firm: Managerial behavior, agency and ownership structure. Journal of Financial Economics, 4, 305-360. http://dx.doi.org/10.1016/0304-405X(76)90026-X

Jiang, W., Lee, P., \& Anandarajan, A. (2008). The association between corporate governance and earnings quality: further evidence using Gov-score. Advances in Accounting, 24, 191-201. http://dx.doi.org/10.1016/j.adiac.2008.08.011

Jones, J. J. (1991). Earnings Management during Import Relief Investigations. Journal of Accounting Research, 29, 193-228. http://dx.doi.org/10.2307/2491047

Jouber, H., \& Fakhfakh, H. (2012). Earnings management and board oversight: an international comparison. Managerial Auditing Journal, 27(1), 66-86. http://dx.doi.org/10.1108/02686901211186108

Klein, A. (2002). Audit committee, board of directors characteristics, and earnings management. Journal of Accounting and Economics, 33(3), 375-400. http://dx.doi.org/10.1016/S0165-4101(02)00059-9

Koh, P. S. (2003). On the association between institutional ownership and aggressive corporate earnings management in Australia. The British Accounting Review, 35, 105-128. http://dx.doi.org/10.1016/S0890-8389(03)00014-3

La Porta, R., Lopez-de-Silanes, F., \& Shleifer, A. (1999). Corporate ownership around theworld. Journal of Finance, 54, 471-517. http://dx.doi.org/10.1111/0022-1082.00115

Loderer, C., \& Peyer, U. (2002). Board overlap, seat accumulation and share prices. European Financial Management, 8, 165-192. http://dx.doi.org/10.1111/1468-036X.00183

Park, Y. W., \& Shin, H. H. (2004). Board composition and earnings management in Canada. Journal of Corporate Finance, 10, 431-457. http://dx.doi.org/10.1016/S0929-1199(03)00025-7

Peasnell, K. V., Pope, P. F., \& Young, S. (2005). Board Monitoring and Earnings Management: Do Outside 
Directors Influence Abnormal Accruals? Journal of Business Finance and Accounting, 32(7\&8), 1311-1346. http://dx.doi.org/10.1111/j.0306-686X.2005.00630.x

Rahman, R., \& Ali, F. (2006). Board, audit committee, culture and earnings management: Malaysian evidence. Managerial Auditing Journal, 21(7), 783. http://dx.doi.org/10.1108/02686900610680549

Sanchez-Ballesta, J., \& Garcia-Meca, E. (2007). Ownership structure, discretionary accruals and the informativeness of earnings. Corporate Governance: An International Review, 15, 677-691. http://dx.doi.org/10.1111/j.1467-8683.2007.00596.x

Santiago, M., \& Brown, C. (2009). An empirical analysis of Latin American board of directors and minority shareholders' rights. Forum Empresarial, 14(2), 1-18.

Schipper, K. (1989). Commentary on earnings management. Accounting Horizons, 3(4), 91-102.

Senteza, J. D., Njoroge, J., \& Gill, S. (2005). Earnings management: Do large investors care? Financial Decisions, 17(3), 2 .

Shaikh, A. M., Iqbal, M. J., \& Shah, S. Z. A. (2012). Institutional Ownership and Discretionary Accruals: Empirical Evidences from Pakistani Listed Non-Financial Companies. Information Management Business Review, 4(4), 217-222.

Stulz, R. (1988). Managerial Control of Voting Rights. Journal of Financial Economics, $20,25-54$. http://dx.doi.org/10.1016/0304-405X(88)90039-6

Tabachnick, B. G., \& Fidell, L. S. (2001). Using Multivariate Statistics (6th ed.). Boston: Pearson.

Teoh, S. H., Welch, I., \& Wong, T. J. (1998). Earnings management and the long-run market performance of initial public offerings. Journal of Finance, 53(6), 1935-1974. http://dx.doi.org/10.1111/0022-1082.00079

Teshima, N., \& Shuto, A. (2008). Managerial ownership and earnings management: Theory and empirical evidence from Japan. Journal of International Financial Management and Accounting, 19(2), $107-132$. http://dx.doi.org/10.1111/j.1467-646X.2008.01018.x

Vafeas, N. (2000). Board Structure and the Informativeness of Earnings. Journal of Accounting and Public Policy, 19(2), 139-160. http://dx.doi.org/10.1016/S0278-4254(00)00006-5

Warfield, T. D., Wild, J. J., \& Wild, K. L. (1995). Managerial ownership accounting choices, and informativeness of earnings. Journal of Accounting and Economics, 20, 61-91. http://dx.doi.org/10.1016/0165-4101(94)00393-J

Xie, B, Davidson, W. N., \& DaDalt, P. J. (2003). Earnings management and corporate governance: the role of the board and the audit committee. Journal of Corporate Finance, 9, $295-316$. http://dx.doi.org/10.1016/S0929-1199(02)00006-8

Yang, C. Y., Lai, H. N., \& Tan, B. L. (2008). Managerial ownership structure and earnings management. Journal of Financial Reporting \& Accounting, 6(1), 35-53. http://dx.doi.org/10.1108/19852510880000634

Yang, W. S., Chun, L. S., \& Ramadili, S. M. (2009). The Effect of Board Structure and Institutional Ownership Structure on Earnings Management. International Journal of Economics and Management, 3(2), 332-353.

Yeo, G., Tan, P., Ho, K., \& Chen, S. (2002). Corporate ownership structure and the informativeness of earnings. Journal of Business Finance and Accounting, 29(7), 1022-1046.

Yermack, D. (1996). Higher Market Valuation of Companies with a Small Board of Directors. Journal of Financial Economics, 40(2), 185-211. http://dx.doi.org/10.1016/0304-405X(95)00844-5

Note

Note 1. $\mathrm{TACC}_{\mathrm{it}}=\mathrm{NI}_{i t}-\mathrm{OCF}_{i t}$ is the difference between earnings and cash flows from operations. $\mathrm{N}_{i t}$ is the net income before extraordinary items for firm $i$ in year $t, \mathrm{OCF}_{i t}$ is the operating cash flows for firm $i$ in year $t$.

\section{Copyrights}

Copyright for this article is retained by the author(s), with first publication rights granted to the journal.

This is an open-access article distributed under the terms and conditions of the Creative Commons Attribution license (http://creativecommons.org/licenses/by/3.0/). 